\title{
Is Online Distance Learning Compatible with Student Lifestyle? Assessment of program content, workload and long-time usefulness
}

\author{
Sunday Adewale Olaleye \\ Dept. of marketing, Management and \\ International Business \\ University of Oulu \\ Oulu, Finland \\ sunday.olaleye@oulu.fi
}

\author{
Ismaila Temitayo Sanusi \\ School of Computing \\ University of Eastern Finland \\ Joensuu, Finland \\ ismails@uef.fi \\ Solomon Sunday Oyelere \\ School of Computing \\ University of Eastern Finland \\ Joensuu, Finland \\ solomon.oyelere@uef.fi
}

\author{
Friday Joseph Agbo \\ School of Computing \\ University of Eastern Finland \\ Joensuu, Finland \\ fridaya@uef.fi
}

\begin{abstract}
Online distance learning (ODL) is gaining rapid acceptance in the educational system, and the level of student enrollment is massive nowadays. Although the adoption of online distance learning seems to be influencing students learning experience, the aspect of compatibility with the student lifestyle remains unclear and needs further research. This study employed a quantitative methodology to describe the relationship between the chosen independent and dependent variables adapted from the existing literature objectively and used structural equation modelling with SmartPLS for the data analysis. This study contributes to the literature on online distance learning and information systems. It gives a comprehensive understanding of how program content positively relates to online academic workload and how the long-time usefulness of online distance learning relates to the workload of online distance learning for the ODL students' lifestyle. This insight shows the importance of program content as a determinant of workload. It also shows how the memory of the long-time usefulness aids the workload of the ODL. The study explains the theoretical contributions, implications and suggests future research.
\end{abstract}

Keywords-online distance learning; program content; workload; student lifestyle; compatibility

\section{INTRODUCTION}

Online distance learning (ODL) is gaining rapid acceptance in the educational system, and the level of student enrollment is massive nowadays [1] [2]. Online learning refers to the application of technology in providing teaching and learning via digital gadgets such as smartphones, laptops, and desktops. These gadgets are interconnected using the internet to allow the exchange of learning resources and instructions. Aside from the convenience and flexibility that ODL provides [3], it also allows education institutions to offer a wide range of accessible degrees to students from different locations. Additionally, research has shown that the ubiquitous nature of ODL allows students to have full control of their learning time and goals [4]. Good as it seems, ODL takes a virtual learning approach whereby the course instructor and learners do not have the opportunity to interact as practiced in a traditional classroom setting. Therefore, it is challenging for instructors, administrators, and other stakeholders that offers ODL to evaluate its compatibility with students' lifestyle.

These days, some of the common issues facing ODL mentioned by Kebritchi et al. [5]. The authors categorized their findings into three issues: online learners, instructors, and content development. In the learner's aspect, challenges such as their readiness, expectations, and identity are some of the factors that determine ODL success. Besides, learners' characteristics such as lifestyle can also influence their motivation towards continuing and completing an online distance learning course and their overall academic performance. The term "lifestyle" has been used in literature, majorly in three different versions but having the same meaning. As asserted by Veal [6], the term can serve as two separate words life style, hyphenated word lifestyle, and oneword lifestyle. The single word version applies in this paper except for citing authors who may have used other versions. There exist many definitions of the term lifestyle. While this study is not focusing on the concept of lifestyle, it recognizes the age-long extensive use of the concept among philosophers [6]. According to Oxford Learner's Dictionary, a simple definition of lifestyle is "how a person or a group of people lives and works." In particular, the student lifestyle describes as balancing between many different roles and activities a student embarks upon [7]. It can also refer to the student's activities (active or inactive) during the academic time [8]. Examples of students' active times include reading, writing, and taking part in debates; other inactive times include sleeping time or taking part in other leisure.

Studies conducted on the impact of students' lifestyles on academic performance from different perspectives are exemplary. For example, Heidari et al. [9] conducted a study to examine the correlation between student lifestyle and academic achievement among nursing students. Similarly, Rajendran [10] recently conducted a study to investigate the influence of lifestyle on middle-school and high-school students' academic performance. Besides, a study investigates issues regarding personality preferences' effect on online distance learners' performance and satisfaction conducted by Bishop-Clark et al. [11]. While these studies have presented relevant contributions to the body of literature, an investigation of how compatible is a distance learning course with students' lifestyles needs exploration. This study aspect is necessary since an ODL that does not consider learners' lifestyle can cause student attrition [2]. Besides, this study is also significant because stakeholders in ODL need to be aware of the influence critical components of online courses such as program content, workload, and long-time usefulness have on students' lifestyles. This knowledge will aid smart decision-making while planning 
and designing online courses compatible with the student lifestyle.

This study investigates the compatibility of ODL with student lifestyle by examining the contents of ODL, its workload, and long-time usefulness. Besides, this study presents four hypotheses and tested them by employing a structural modelling approach using SmartPLS software. The study expects to test variables such as workload, program content, long-time usefulness, and distance instruction to determine the motivators and inhibitors of ODL on compatibility with the student lifestyle. This study reviewed related literature in part two. Part three explains the methodology. Part four describes the data analysis technique and presents the findings of the study. The final part explicates the theoretical contribution, practical implications, limitation, and offers a useful suggestion for the future study.

\section{LITERATURE REVIEW}

Online learning represents the technology application in the education field, and it has increasingly been studied [3]. This section reviewed relevant literature based on the Distance Instruction, Program Content, Workload, Long Time Usefulness and Compatibility for Lifestyle that guided the study. This review suggests four hypotheses for testing.

\section{A. Distance Instruction (DI)}

Online distance learning, where teachers instruct students despite students and teachers' wide separations, is increasingly popular. New and emerging technologies have made it technically possible to meet pressing worldwide demands for literacy training through distance instruction. Knowledge gained from a substantial body of experience in distance instruction is available to help educators combine technology with effective pedagogical programs. Earlier studies [12] on distance instruction show that the interaction between distance teaching and student evaluation of teaching effectiveness influenced online materials and student-perceived learning outcomes. It further revealed that the quality of distance instruction, student evaluation of teaching effectiveness, and online materials are the keys to successful distance instruction [12]. This study infers that Distance Instruction of online distance learning positively predicts the compatibility of the student lifestyle.

Thus, we hypothesized that:

H1: Distance Instruction of online distance learning positively predicts the compatibility of the student lifestyle.

\section{B. Program Content (PC)}

In this study, program content is the set of activities or concepts designed for an online distance education program, including learning content. UNESCO-IBE [13] described learning content as the topics, themes, beliefs, behaviors, concepts, and facts, often grouped within each subject or learning area under knowledge, skills, values, and expected attitudes to be learned and form the basis of teaching and learning. Course designers and teachers create the content in online education courses and develop learning materials that they want to use in several courses and various formats. For instance, the program enables flexibility and content that allows personalization and adaptation to students' expectations and needs; it will likely be compatible with their lifestyle. This study assumes that the online program's content may predict the compatibility of students' lifestyles. Therefore, we hypothesized that:

H2: Program content of online distance learning positively predicts the compatibility of the student lifestyle.

\section{Workload (WL)}

In this study, the workload is the amount of work done by a student in an online distance education course. Workload issues are the most significant barrier in adopting online education because educators perceive the workload to be higher than that of traditional courses [14]. According to Ingusci, Spagnoli, Zito, Colombo \& Cortese, [15], the workload is concerned with the feeling that one has too many things to do in too little time. The study of [16] shows that workload and time pressure were strongly related to emotional exhaustion. The workload often studied concerning exhaustion because of the increased effort needed when individuals feel that they need to do more at work. In an online distance education setting, [14] study shows that operating in the online environment increases workload and hugely increases the number of contact hours. Based on this argument, this study assumes that content designed for the program can positively affect the workload of the distance program. For this reason, we hypothesize that:

H3: Program content of online distance learning positively predicts the workload of the distance program.

\section{Long-time Usefulness (LTU)}

Perceived usefulness is the extent to which target users believe that using IT will create significant value for them [17]. Olaleye, Sanusi, Salo, and Okunoye [18] describes technology usefulness as the degree to which a user believes it will be of more benefit and add value to him. The study of [19] shows that perceived usefulness significantly impacts user attitudes, with a relative impact on user adoption and satisfaction. The meaningful association established among real use of technologies and satisfaction as well as performance [20];[21];[40]. This research proposes that the longer the duration and frequencies of usage of online technologies among students, the lesser the feelings that online distance learning increases workload and hugely increases the number of contact hours. This study assumes that if a student believes that online distance learning has been beneficial after several years of its adoption, it will affect the workload. In this study, we argue that the longtime usefulness will affect the workload of the distance program.

Therefore, we hypothesized that:

H4: Longtime usefulness of online distance learning positively predicts the workload of the distance program.

\section{E. Compatibility for Lifestyle (CFL)}

Roger [22] described compatibility as the intensity with which innovations are perceived to align with their probable adopters' current needs, values, and prior experiences. This study defines it as the degree to which taking an online distance course is perceived as being consistent with students' lifestyles. Studies [23];[24] have shown that high compatibility leads to an increased chance of technology adoption. Cheng, [25] and [26] also considered 
compatibility as one of the fundamental antecedents to user adoption of new technology or application. Ozturk et al. [26] described CFL as the intensity with which online learning technologies fit student beliefs, values, and lifestyles. The study of [25] discovers that a relationship exists between usage and compatibility regarding mobile learning programmes.

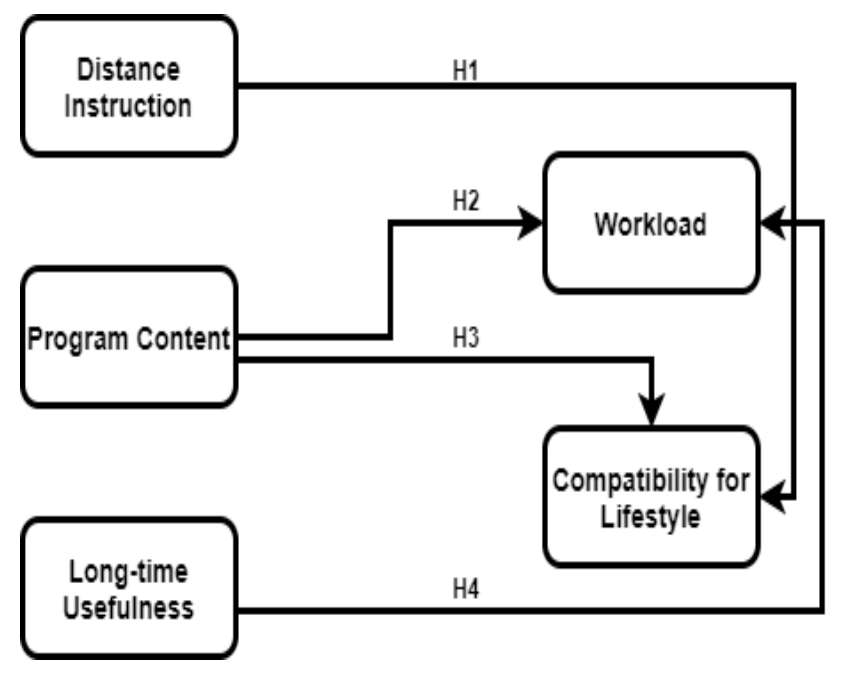

Figure 1. Research model showing the connection between the variables and hypothesis

\section{Hypothesis Development}

The followings are the hypothesis generated to establish the relationship among the variables:

Distance instruction as a predictor of compatibility for lifestyle

H1: Distance instruction of online distance learning positively predicts the compatibility of the student lifestyle.

Program content as a predictor of compatibility for lifestyle $\mathrm{H} 2$ : Program content of online distance learning positively predicts the compatibility of the student lifestyle.

Program content as a predictor of workload

H3: Program content of online distance learning positively predicts the workload of the distance program.

Long time usefulness as a predictor of workload

H4: Longtime usefulness of online distance learning positively predicts the workload of the distance program.

\section{Moderation}

H5: Online complete course moderates between long-time usefulness and online distance learning compatibility of the student lifestyle

\section{METHODOLOGY}

This study employed a quantitative methodology to describe the relationship between the chosen independent and dependent variables adapted from the existing literature objectively. Also, this study used structural equation modelling with version 3.2 .8 of SmartPLS for both measurement and the analysis of the structural relationship of distance instruction, long time usefulness, program content, the workload of online distance learning as a direct and indirect predictor of compatibility for lifestyle. The study also conducted moderation analysis and examined how the online-completed course moderates the relationship between long-time usefulness and lifestyle compatibility. The study conducted Importance-Performance Analysis with SmartPLS based on distance instruction attributes, program content, workload, long-time usefulness, and compatibility for lifestyle to ascertain the quality characteristics and satisfaction of online distance learning users. Table I shows the respondent's demography.

\section{TABLE I. DEMOGRAPHY FREQUENCY}

\begin{tabular}{|c|c|c|c|}
\hline Item & Classification & Frequency & Percentage\% \\
\hline \multirow[t]{5}{*}{ Age } & 17 or younger & 1 & 0.8 \\
\hline & $18-25$ & 3 & 2.4 \\
\hline & $26-35$ & 68 & 54.4 \\
\hline & $35-45$ & 47 & 37.6 \\
\hline & 45 and above & 6 & 4.8 \\
\hline \multirow[b]{2}{*}{ Gender } & Male & 100 & 80 \\
\hline & Female & 25 & 20 \\
\hline \multirow{5}{*}{ Education } & High School & 14 & 11.2 \\
\hline & Bachelor's Degree & 78 & 62.4 \\
\hline & Master's Degree & 28 & 22.4 \\
\hline & Ph.D. & 2 & 1.6 \\
\hline & Post Doc. & 3 & 2.4 \\
\hline \multirow{8}{*}{ Occupation } & Construction & 6 & 4.8 \\
\hline & Estate Management & 9 & 7.2 \\
\hline & Education & 4 & 3.2 \\
\hline & Student & 78 & 62.4 \\
\hline & Manufacturing & 3 & 2.4 \\
\hline & Marketing & 8 & 6.4 \\
\hline & Inform. Tech. & 16 & 12.8 \\
\hline & Others & 1 & 0.8 \\
\hline \multirow{6}{*}{ Income } & Less than $€ 1,500$ & 86 & 68.8 \\
\hline & $€ 1,501-€ 2,500$ & 26 & 20.8 \\
\hline & $€ 2,501-€ 3,500$ & 5 & 4.0 \\
\hline & $€ 3,501-€ 4,500$ & 3 & 2.4 \\
\hline & $€ 4,501-€ 5,500$ & 1.6 & 1.6 \\
\hline & $€ 5,501$ or more & 3 & 2.4 \\
\hline \multirow{4}{*}{$\begin{array}{l}\text { Computer use } \\
\text { experience }\end{array}$} & Less than 1 year & 2 & 1.6 \\
\hline & 1 year & 2 & 1.6 \\
\hline & 2 years & 5 & 4.0 \\
\hline & 3 years $\&$ above & 116 & 92.8 \\
\hline Online & & & \\
\hline Completed & Yes & 81 & 64.8 \\
\hline Course & No & 44 & 35.2 \\
\hline
\end{tabular}

\section{Sample and Data Collection}

This study draws its sample from the students and workers in Finnish Universities that attempt online distance learning at one time or the other. The adapted structured questionnaire relevant to online distance learning administered through Survey Monkey online survey platform. One hundred and sixty (160) respondents participated in this study. Only 125 responses were useful after the statistical cleaning process. The first section of the questionnaire, background information, contains general questions about the respondents' sex, age, occupation, academic attainment, salary and computer experience, and online-completed course. Regarding the survey participants' characteristics, 100 males (80\%) and 25 females (20\%) reflect in the descriptive statistics. The participants' education levels account for $62 \%$ of bachelor's degree holders and $22 \%$ of master's degree holders. Similarly, the participants who have undertaken online courses are $65 \%$, while $35 \%$ are not familiar with online courses (Table I). Generally, ages 17 through 45 answered the questionnaire. The most significant percentage of participants has practically experienced online courses. Tables II, III, and IV show reliability test, factor loadings, average variance extracted (AVE), and composite reliability (CR). 
TABLE II. ITEMS ReliabILITY TEST RESUlts

\begin{tabular}{|l|l|}
\hline Latent Variable and its items & $\begin{array}{l}\text { Items } \\
\text { Reliability } \\
\text { test results }\end{array}$ \\
\hline $\begin{array}{l}\text { Distance Instruction } \\
\text { Distance instruction is available to help me if I have any question } \\
\text { on the course }\end{array}$ & 0.940 \\
$\begin{array}{l}\text { I can easily find someone online to help me if I have any difficulties } \\
\text { If I have question on the course I know who I can ask online }\end{array}$ & 0.940 \\
\hline $\begin{array}{l}\text { Program Content } \\
\text { Online distance learning provides up-to-date courses }\end{array}$ & 0.940 \\
$\begin{array}{l}\text { Online distance learning provides sufficient courses } \\
\text { Online distance learning provides courses which I need }\end{array}$ & 0.939 \\
\hline $\begin{array}{l}\text { Long-time Usefulness } \\
\text { Using online distance learning help me to gain success in the future }\end{array}$ & 0.939 \\
$\begin{array}{l}\text { Using online distance learning benefit, me in the long run } \\
\text { Using online distance learning help me to meet my future target }\end{array}$ & 0.939 \\
\hline $\begin{array}{l}\text { Workload } \\
\text { The work load of online distance learning is high }\end{array}$ & 0.939 \\
I find it difficult to meet the demand of online distance learning \\
$\begin{array}{l}\text { work load } \\
\text { There are too much workload of online distance learning }\end{array}$ & 0.942 \\
\hline $\begin{array}{l}\text { Compatibility for Lifestyle } \\
\text { Online distance learning is compatible with my learning style and } \\
\text { habits }\end{array}$ & 0.944 \\
$\begin{array}{l}\text { Online distance learning is suitable for my learning style } \\
\text { Online distance learning is compatible with my learning style to use } \\
\text { online contents }\end{array}$ & 0.939 \\
\hline $\begin{array}{l}\mid \\
\text { and }\end{array}$ & 0.939 \\
\hline
\end{tabular}

\section{Measurement Items}

This study utilized five interrelated latent variables to online distance learning with five Likert-scales ranging from (1) disagree and (5) agree. The measurement for compatibility for lifestyle was adapted from the study of [27];[28];[29], distance instruction [30];[31];[29], long time usefulness [29], program content [29]; [32] and workload [31]; [29]. These variables are very crucial for the testing of the hypothesis in this study.

TABLE III. OVERALL CFA FOR THE MEASUREMENT MODEL

\begin{tabular}{|c|c|c|c|}
\hline & rho_A & CR & AVE \\
\hline Compatibility for Lifestyle & 0.91 & 0.94 & 0.85 \\
\hline Distance Instruction & 0.84 & 0.88 & 0.71 \\
\hline Long Time Usefulness & 0.87 & 0.92 & 0.79 \\
\hline Program Content & 0.85 & 0.90 & 0.74 \\
\hline Workload & 0.91 & 0.86 & 0.68 \\
\hline
\end{tabular}

TABLE IV. INNER AND OUTER VIF VALUES

\begin{tabular}{|l|c|c|c|c|}
\hline MV and V R & $\begin{array}{l}\text { Item } \\
\text { loadings }\end{array}$ & Mean & SD & VIF \\
\hline CFL & 0.92 & 3.66 & 1.14 & N/A \\
CFL1 & 0.93 & 3.71 & 1.17 & 3.70 \\
CFL2 & 0.91 & 3.74 & 1.14 & 2.83 \\
CFL3 & & & & 1.45 \\
\hline DI->CFL & 0.75 & 3.74 & 1.05 & 1.71 \\
DI1 & 0.91 & 3.56 & 1.08 & 2.32 \\
DI2 & 0.86 & 3.76 & 1.17 & 1.67 \\
DI3 & & & & 1.58 \\
LTU->WL & 0.88 & 3.50 & 1.06 & 2.35 \\
LTU1 & 0.88 & 3.80 & 0.98 & 2.06 \\
LTU2 & 0.90 & 3.55 & 1.03 & 2.48 \\
LTU3 & 0.87 & 3.90 & 1.03 & 1.79 \\
\hline PC->CFL & 0.86 & 3.43 & 1.14 & 2.18 \\
PC1 & 0.85 & 3.54 & 1.06 & 1.90 \\
PC2 & & & & 1.00 \\
PC3 & 0.88 & 3.50 & 1.05 & 1.46 \\
\hline PC->WL & 0.75 & 3.01 & 1.10 & 1.90 \\
WL1 & 0.84 & 3.16 & 1.10 & 2.35 \\
WL2 & & & & \\
WL3 &
\end{tabular}

MV: Manifest Variables; VR: Variable Relationship; SD: Standard Deviation VIF: Variance Inflation Factor

\section{RESULT}

This study subjects the variables used to measure and structural modelling for quality criteria and hypothesis testing with SmartPLS. In the first stage, this study conducted data analysis to ascertain the quality of the measurement model and examined the distance online course compatibility for lifestyle, workload, long-time usefulness items reliability, and factor loadings. In the second stage, the study employed the bootstrapping technique to examine the significance and insignificance of the hypothesis tested using thresholds of 1.96 and two-tailed significant levels.

\section{Measurement Model}

This study utilized SmartPLS and SPSS 26.0 for reliability test (Cronbach's alpha $\alpha$ ), factor loadings, average variance extracted (AVE), and composite reliability (CR). The results are shown in Tables II, III, and IV). The factor loadings results show a reliable loading and range between 0.75 and 0.93 , while the factor loading values are higher than the required 0.5 . Also, the composite reliability values equal to and greater than the boundary of 0.7 . The results show a minimum of 0.86 and a maximum of 0.94 and likewise with average variance extracted with a minimum of 0.68 and a maximum of 0.85 . All the values are higher than the thresholds of 0.5 . Rho_A, a more reliable test, also shows a good result. The Variance Inflation Factor (VIF) results also show that the measurement's multicollinearity is not outrageous. Table IV also shows the mean and standard deviation values for each item. The Cronbach's alpha results depict the adapted scales' reliability with a minimum of 0.939 and a maximum of 0.944. All the values are higher than the threshold of 0.7 . Table $\mathrm{V}$ shows the study's discriminant validity and the correlation of the items. The average of the square root of each latent variable is higher than the underlying values.

\section{Structural Model}

The result shows that out of the four hypotheses, it is only two that were significant. The following are the details of this study result. For reliability and validity of the study, the composite reliability, rho_A, and average variance extracted yielded the right values according to the uniformed standard. Similarly, the Variance Inflation Factor (VIF) loaded well (see tables 1 and 2 for details). Distance instruction predicts compatibility for lifestyle, (DI -> CFL, $\beta$ $=0.15$ and $\mathrm{t}=1.62$ and the proposed hypothesis was not significant (H1). Besides, program content predicts compatibility for lifestyle, $(\mathrm{PC} \rightarrow \mathrm{CFL}, \beta=0.09$ and $\mathrm{t}=$ 0.92 ) and the result is similar to $\mathrm{H} 1$. Further, program content relates with workload, $(\mathrm{PC}-\mathrm{WL}, \beta=0.30$ and $\mathrm{t}=$ 3.11) and it is highly significant while long-time usefulness relates to workload (LTU $\rightarrow \mathrm{WL}, \beta=0.53$ and $\mathrm{t}=6.58(\mathrm{H} 4)$ and the result similar to $\mathrm{H} 3$. The moderator hypothesis (CFL -> LTU $x$ OCC), $\beta=0.15$ and $t=2.55$. The H5 implies that long-time usefulness and online-completed course moderates compatibility for lifestyle is significant. Out of all the hypotheses tested, the path coefficient of PC-> WL and LTU $\rightarrow$ WL has the highest explanatory power. The path coefficient of determination for workload variance explained $7.3 \%$, while the overall variance (compatibility 
for lifestyle) explained, $44.1 \%$ which is between weak and moderate criterion (see Figure 2). This study probed into the importance and performance of the constructs utilized as an extension of structural equation modelling (SEM) to prioritize managerial actions. Besides the SEM results, the study conducted Importance-Performance Map Analysis (IPMA) and examined three constructs, that is, program content (Y1), distance instruction (Y2), and long-time usefulness (Y3). The results show that long-time usefulness (0.53) (Y3) is the most critical construct for online distance learning among all the constructs. Distance instruction follows in turn with $(0.15)(\mathrm{Y} 2)$, and lastly, program content (0.10) (Y1). The results of the performance of the constructs are the opposite of its importance. Distance instruction (Y2) is the most performing construct with $66.9 \%$, followed by program content $66.4 \%$ (Y1) and long-time usefulness with $65.7 \%$ (Y3). All the constructs' performance was very close and fall within the average value of $66.2 \%$, while the average value for importance constructs records 0.29 while considering the performance scores on a scale from 0 to 100.

TABLE V. CORRELATIONS OF LATENT VARIABLE

\begin{tabular}{|c|c|c|c|c|c|}
\hline $\begin{array}{c}\text { Latent } \\
\text { Variable }\end{array}$ & CFL & DI & LTU & $\mathrm{PC}$ & WL \\
\hline CFL & 0.92 & & & & \\
\hline DI & 0.42 & 0.84 & & & \\
\hline LTU & 0.64 & 0.44 & 0.89 & & \\
\hline PC & 0.47 & 0.53 & 0.59 & 0.86 & \\
\hline WL & 0.09 & 0.12 & 0.24 & 0.27 & 0.82 \\
\hline
\end{tabular}

TABLE VI. STANDARDIZED PATH COEFFICIENTS AND CORRESPONDING HYPOTHESIS RESULTS

\begin{tabular}{|c|c|c|c|c|c|}
\hline HYP & LVR & Beta & SD & T values & Comment \\
\hline H1 & DI -> CFL & 0.15 & 0.09 & 1.62 & NS \\
\hline H2 & PC -> CFL & 0.09 & 0.10 & 0.92 & NS \\
\hline H3 & PC-> WL & 0.30 & 0.09 & $3.11^{* * *}$ & S \\
\hline H4 & LTU -> WL & 0.53 & 0.08 & $6.58^{* * *}$ & S \\
\hline H5 & CFL (LTU x OCC) & 0.15 & 0.06 & $2.55^{* *}$ & S \\
\hline \\
LVR: Latent Variable Relationship; SD: Standard Deviation; NS: Not Supported; S: Supported; OCC: Online Complete \\
Course
\end{tabular}

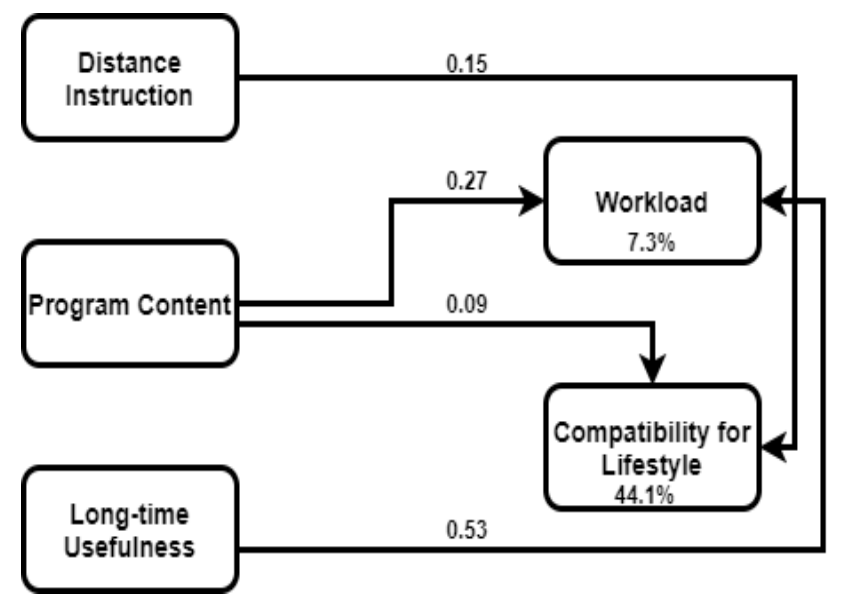

Figure 2. Results of tested hypothesis

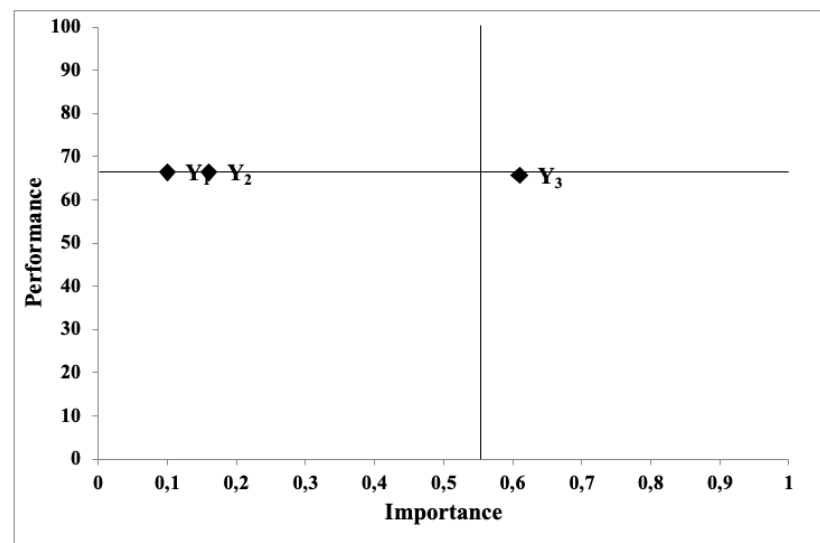

Figure 3: Results of Importance-Performance Analysis

Note: $Y_{1}$ : Program Content; $Y_{2}$ : Distance Instruction; $Y_{3}$ : Long-time Usefulness

\section{DISCUSSION}

\section{Theoretical Contribution}

The on-going COVID-19 pandemic proves inimical to the world educational systems which if not properly managed, can devalue the education standard and leads to unbanked graduates in different sphere of the educational system. Online distance learning is one of the fastest solutions to the lockdown of global educational systems. Online distance learning is an effective means of promoting social distancing, and it has the potential for transferable skills, effective time management, socialization by utilizing a variety of education technology. Online distance learning is becoming affordable due to the global Internet diffusion, it is flexible, it facilitates student and teachers networking, and its quality has appreciated dramatically. This study contributes to the literature of online distance learning and information systems by giving a comprehensive understanding of how program content positively relates to online academic workload and how the long-time usefulness of online distance learning relates to the workload of the ODL students. This result shows the importance of program content as a determinant of workload and how the memory of the long-time usefulness can aid the online academic workload.

This study combined essential constructs crucial for the development of online distance learning and endeavoured to examine how online distance programs fit the student lifestyle. This study contributes to the body of knowledge in two parts. First, this study clarifies the factors that make online distance programs compatible for student's lifestyles and gives an understanding that the perception of long-time usefulness of online distance program accomplishment is the highest factor to consider for student workload. Besides, this study deepens our understanding of the relationship between online distance program content, long-time usefulness and its workload. Reasonably, the higher the distance online program content, the higher the workload associates with it. Second, this study also gives enlightenment on how the online completed course moderates the relationship of longtime usefulness and compatibility for lifestyle and shows that a high online completed course is stronger than the low online completed course based on the long-time usefulness perception. This study contributes to online distance learning 
literature by introducing an online distancing learning framework for student compatibility for lifestyle. This study found the factors responsible for student compatibility for lifestyle while engaging in online distance learning in a developed country and the importance of long-time usefulness. The study also shows the direct relationship and indirect relationship of the constructs employed.

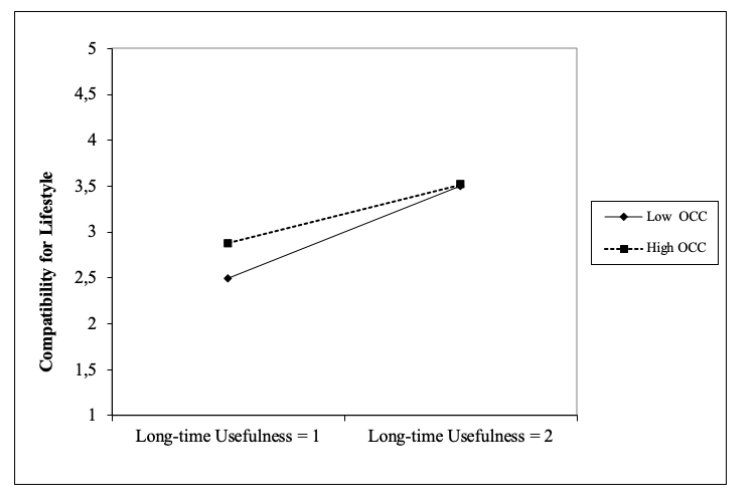

Figure 4: Interaction effect between Long-time Usefulness x Online Complete Course on Compatibility for Lifestyle

\section{Managerial Implication}

The Importance-Performance Map gives managerial insights in three ways. First, the education manager needs to improve the program content of online distance learning materials and properly tailored-made it for online use. The richness of the program content and ease of use will position the program in the student's heart as a vital element of online distance learning. Besides, since innovation and technology are not constant but dynamic in all facets, this study suggests to the education managers to migrate from archaic education technology tools and adopt innovative, robust Education Management Information Systems (EMIS) and smart learning environment that connect teachers, students, and others online distance learning stakeholders. Though the importance value of long-time usefulness is a bit above average, unlike program content and distant instruction constructs that recorded low importance values. It is proposed to the education managers to increase long-time usefulness perception of online distance learning in the students' minds through online publicity and ads so that it can be possible to track the student's progress through analytics. Second, the performance of program content, distance instruction, and long-time usefulness performance values are at the border of average. It means there is a need for improvement, and this study suggests to the education managers to improve the performance of these three constructs. This study suggests to online distance learning managers and other online course stakeholders to pay close attention to the dramatic influence of program content, workload, as a green light for the compatibility of ODL for the student's lifestyle. The managers should enhance these aspects of ODL. Regarding ODL contents and resources, this study suggests that designers, managers, and other stakeholders of ODL should consider adopting the open educational resources (OER) model [36][37]. Recently, scholars have argued the importance of adopting OER to provide flexible learning in ODL, especially in a pandemic where schools are closed [38][39].

\section{Study Limitation and Future Study}

This study dwells on the student's community but did not concentrate fully on the companies and international organizations that utilize ODL for their busy employees. Future research should expand this study and portray ODL as a multidimensional research domain. Furthermore, future research could use a more extensive scale study with a more representative sample to validate the model presented in this study and enhance the research conclusions' generalizability. In addition, this study examined only the effect of the motivators and inhibitors on compatibility with lifestyle. Due to this limitation, this study recommends the investigation of interrelationships between variables.

Furthermore, the workload associated with online and blended teaching is ill defined, and the numbers and nature of tasks associated with online and blended teaching are poorly understood [33]. Especially in the perspective of students, as evident in several kinds of literature [9]; [34]; [35] that educators perceive workload to be higher and timeconsuming. This insight has implications for researchers and practitioners interested in exploring workloads in online education.

\section{REFERENCES}

[1] M. Ferrer, "What do higher education students know about massive open online courses?" New Trends and Issues Proceedings on Humanities and Social Sciences, vol. 4, pp. 115-122, 2017.

[2] K.M. Law, S., Geng, \& T. Li, “ Student enrollment, motivation and learning performance in a blended learning environment: The mediating effects of social, teaching, and cognitive presence". Computers \& Education, vol. 136, pp. 1-12, 2019.

[3] O. Isaac, A. Aldholay, Z. Abdullah and T. Ramayah, "Online learning usage within Yemeni higher education: The role of compatibility and task-technology fit as mediating variables in the IS success model," Computers \& Education, vol. 136, pp. 113-129, 2019.

[4] M. Gagne and M. Shepherd, "Distance Learning in Accounting," THE Journal (Technological Horizons In Education), vol. 28, 2001.

[5] M. Kebritchi, A. Lipschuetz, L. Santiague, "Issues and Challenges for Teaching Successful Online Courses in Higher Education: A Literature Review". Journal of Educational Technology Systems, vol. 46, pp. 4-29, 2017.

[6] A.J. Veal, "The concept of lifestyle: a review". Leisure Studies, vol. 12, pp. 233-252, 1993

[7] V. Bocsi, "The Share of Academic Time in Student Lifestyle," HERJ Hungarian Educational Research Journal, vol. 3, pp. 77-88, 2013.

[8] T. Gray and J. Oslin, "Primary school students' choices for a healthy active lifestyle," Journal of Physical Education, Recreation \& Dance, vol. 74, pp. 52-57, 2003

[9] M. Heidari, M. Borujeni, M. Borujeni and M. Shirvani, "Relationship of lifestyle with academic achievement in Nursing students," Journal of Clinical and Diagnostic Research: JCDR, vol. 11, 2017.

[10] S. Rajendran and S. Chamundeswari, "Understanding the impact of lifestyle on the academic performance of middle-and high-school students," Journal of Sociological Research, vol. 10, pp. 67-79, 2019.

[11] C. Bishop-Clark, B. Dietz-Uhler, A. Fisher, "The effects of personality type on web.based distance learning". Journal of educational systems, vol. 35, pp. 491-506, 2007.

[12] H.P. Yueh, C. Liang, "A Predictive Model of Distance Instruction Integrating Considerations of Students, Teachers, and Instructional Contexts". Journal of Educational Media \& Library Sciences, vol. 52, 2015.

[13] UNESCO-IBE, "Learning Content". Retrieved on December 6, 2019 from terminology/l/learning-content

[14] D.U. Bolliger, O. Wasilik, "Factors influencing faculty satisfaction with online teaching and learning in higher education". Distance education, vol. 30, pp. 103-116, 2009.

[15] E. Ingusci, P. Spagnoli, M. Zito, L. Colombo, C.G. Cortese, "Seeking Challenges, Individual Adaptability and Career Growth in the 
Relationship between Workload and Contextual Performance: A Two-Wave Study”. Sustainability, vol. 11, pp. 422, 2019.

[16] B.L. Rich, J.A. Lepine, E.R. Crawford, "Job engagement: Antecedents and effects on job performance". Acad. Manag. J., vol. 53, pp. 617-635, 2010.

[17] K. Rouibah, H. Abbas, S. Rouibah, "Factors affecting camera mobile phone adoption before e-shopping in the Arab world", Technology in Society, vol. 33, pp. 271-283, 2011.

[18] S.A. Olaleye, J. Salo, I.T. Sanusi, A. Okunoye, "Retailing Mobile App Usefulness: Customer Perception of Performance, Trust and Tension Free". International Journal of E-Services and Mobile Applications (IJESMA), vol. 10, 2018.

[19] T.J. Hess, A.L. McNab, K.A. Basoglu, "Reliability generalization of perceived ease of use, perceived usefulness, and behavioral intentions", MIS Quarterly, vol. 38, 2014.

[20] O. Isaac, Z. Abdullah, T. Ramayah, A.M. Mutahar, "Internet usage, user satisfaction, task-technology fit, and performance impact among public sector employees in Yemen". The International Journal of Information and Learning Technology, vol. 34, pp. 210-241, 2017b.

[21] P.E. Ramirez-Correa, F. J. Rondan-Cataluna, J. Arenas-Gaitan, J.L. Alfaro-Perez, "Moderating effect of learning styles on a learning management system's success". Telematics and Informatics, vol. 34, pp. 272-286, 2017.

[22] E.M. Rogers, "Diffusion of innovations (4th ed.). New York, London: The Free Press, 1995

[23] J.H. Wu, S.C. Wang, "What drives mobile commerce? An empirical evaluation of the revised technology acceptance model", Information \& Management, vol. 42, pp. 719-23, 2005.

[24] J.H. Wu, Y.M. Wang, "Measuring KMS success: A respecification of the DeLone and McLean's model. Information \& Management, vol. 43, pp. 728-739, 2006.

[25] Y. Cheng, "Towards an understanding of the factors affecting mlearning acceptance: Roles of technological characteristics and compatibility". Asia Pacific Management Review, vol. 20, pp. 109$119,2015$.

[26] A.B. Ozturk, A. Bilgihan, K. Nusair, F. Okumus, "What keeps the mobile hotel booking users loyal? Investigating the roles of selfefficacy, compatibility, perceived ease of use, and perceived convenience. International Journal of Information Management, vol. 36, pp. 1350-1359, 2016.

[27] F. Dağ, A. Geçer, "Relations between online learning and learning styles". Procedia-Social and Behavioral Sciences, vol. 1, 862-871, 2009.

[28] D.P. Diaz, R.B. Cartnal, "Students' learning styles in two classes: Online distance learning and equivalent on-campus. College teaching, vol. 47, pp. 130-135, 1999 .
[29] M. Nichols, "Student perceptions of support services and the influence of targeted interventions on retention in distance education". Distance education, vol. 31, pp. 93-113, 2010.

[30] S.J. Mills, M. J., Yanes, C. M., Casebeer, "Perceptions of distance learning among faculty of a college of education". MERLOT Journal of Online Learning and Teaching, vol. 5, pp. 19-28, 2009.

[31] K. Oliver, J. Osborne, K. Brady, "What are secondary students' expectations for teachers in virtual school environments". Distance Education, vol. 30, pp. 23-45, 2009.

[32] E.C. Boling, M. Hough, H. Krinsky, H., Saleem, M. Stevens, "Cutting the distance in distance education: Perspectives on what promotes positive, online learning experiences". The Internet and Higher Education, vol. 15, pp. 118-126, 2012.

[33] Dibiase, D., \& Rademacher, H. J. "Scaling up: Faculty workload, class size, and student satisfaction in a distance learning course on geographic information science" Journal of Geography in Higher Education, vol. 29, pp. 139-158, 2005.

[34] B. Tynan, Y. Ryan, A. Lamont-Mills, "Examining workload models in online and blended teaching". British Journal of Educational Technology, vol. 46, pp. 5-15, 2015.

[35] M. Simonson, S. Smaldino, M. Albright, S. Zvacek, "Teaching and learning at a distance: Foundations of distance education" (4th ed.), Boston: Allyn \& Bacon, 2009.

[36] I. Gil-Jaurena, "Open educational policies and practices in the Spanish National Distance Education University: UNED Abierta (UNED OER programme)". In Proceedings of OpenCourseWare Consortium Global Conference, 2014.

[37] E. Tovar, N. Piedra, "Guest editorial: open educational resources in engineering education: various perspectives opening the education of engineers", IEEE Transactions on Education, vol. 57, pp. 213-219, 2014

[38] E. Tovar, B. Tabuenca, A. Alzaghoul, C. D. KloosSluss, J. LópezRey, Á., ..., S. Martin, "Do MOOCs Sustain the UNESCO's Quality Education Goal?" In 2019 IEEE Global Engineering Education Conference (EDUCON), pp. 1499-1503, 2019.

[39] R. Huang, D. Liu, A. Tlili, S. Knyazeva, T. W. Chang, X. Zhang, ..., C. Holotescu, "Guidance on Open Educational Practices during School Closures: Utilizing OER under COVID-19 Pandemic in line with UNESCO OER Recommendation.” Beijing: Smart Learning Institute of Beijing Normal University, 2020

[40] S. Olaleye, I.T. Sanusi, S.S. Oyelere "Users experience of mobile money in Nigeria". In Proceedings of the 2017 IEEE Science Technology \& Innovation for Africa Conference (AFRICON2017) Advancing Technology for Humanity, pp. 956-961, 2017. 